\title{
Recovery without sequelae from severe methanol intoxication
}

\author{
J. MARTENS \\ M.D. \\ R. VERBERCKMOES \\ M.D.
}

\author{
R. WESTHOVENS \\ M.D. \\ H. DELOOZ \\ M.D., Ph.D.
}

\author{
P. DAENENS \\ M.D.
}

The Departments of Nephrology, Emergency Medicine and Toxicology, University Hospitals K.U. Leuven B-3000 Leuven, Belgium

\begin{abstract}
Summary
A case of massive methanol poisoning is described. The peak serum methanol level of $287.5 \mathrm{mmol} /$ litre $(920 \mathrm{mg} / \mathrm{dl})$ is by far the highest recorded level associated with complete recovery. This successful outcome can probably be attributed to early and prolonged haemodialysis.
\end{abstract}

\section{Introduction}

Methanol poisoning is characterized by central nervous system depression, gastro-intestinal disturbances, high anion gap acidosis and blindness (Bennett et al., 1953; Gonda et al., 1978; Naraqi et al., 1979). The lethal amount of ingested methanol may vary between $30-250 \mathrm{ml}$, but as much as $540 \mathrm{ml}$ has been ingested without permanent sequelae (Bennet $e t$ al., 1953). In most fatal cases serum methanol levels were greater than $31.25 \mathrm{mmol} /$ litre $(100 \mathrm{mg} / \mathrm{dl})$. The highest reported levels not associated with death or visual impairment were $178.1 \mathrm{mmol} /$ litre (570 $\mathrm{mg} / \mathrm{dl})$ and $112.5 \mathrm{mmol} / \mathrm{litre}(360 \mathrm{mg} / \mathrm{dl})$ respectively (Gonda et al., 1978). In this paper we report on a patient who recovered completely from a severe intoxication with a peak serum methanol concentration of $287.5 \mathrm{mmol} / \mathrm{litre}(920 \mathrm{mg} / \mathrm{dl})$.

\section{Case report}

A 39-year-old man weighing $76 \mathrm{~kg}$ with a history of recent ethanol abuse ingested approximately 500 $\mathrm{ml}$ of methanol in a suicidal attempt. Eight hours later he was admitted to the emergency unit in a comatose state. The corneal reflexes were absent, the pupils reacted to light and the ocular fundi were normal. The blood pressure was $135 / 90 \mathrm{~mm} \mathrm{Hg}$, pulse $137 / \mathrm{min}$ and respirations $32 / \mathrm{min}$. The serum sodium concentration was $140 \mathrm{mmol} /$ litre, chloride $94 \mathrm{mmol} /$ litre, potassium $6.4 \mathrm{mmol} /$ litre and carbon dioxide content $10 \mathrm{mmol} /$ litre. The arterial $\mathrm{pH}$ was $7 \cdot 17$ and $\mathrm{PCO}_{2} 26 \mathrm{mmHg}$. The blood urea nitrogen was $10.35 \mathrm{mmol} /$ litre, serum creatinine $187.4 \mu \mathrm{mol} /$ litre and glucose $15.4 \mathrm{mmol} /$ litre. The measured and calculated serum osmolality were 596 and 306 $\mathrm{mOsm} / \mathrm{kg} \mathrm{H}_{2} \mathrm{O}$ respectively. This high osmotic gap corresponded well with the serum methanol concentration of $920 \mathrm{mg} / \mathrm{dl}(=287.5 \mathrm{mmol} /$ litre $)$ as determined by gas chromatography (Roeckel and Talbert, 1970). Ethanol was not detectable.

Notwithstanding treatment with gastric lavage and sodium bicarbonate, the arterial $\mathrm{pH}$ further dropped to 6.98 and the $\mathrm{PCO}_{2}$ increased to $37 \mathrm{mmHg}$. A $5 \%$ ethanol solution was administered intravenously: $50 \mathrm{~g}$ of ethanol during the first hour, $50 \mathrm{~g}$ in the next $4 \mathrm{hr}$ and thereafter $22.5 \mathrm{~g}$ during $4.5 \mathrm{hr}$. Haemodialysis was started $2 \mathrm{hr}$ after admission and was performed with a $1 \mathrm{~m}^{2}$ surface hollow fibre dialyser with a blood flow rate of $250 \mathrm{ml} / \mathrm{min}$ and a dialysate flow rate of $750 \mathrm{ml} / \mathrm{min}$. Further evolution and details concerning the treatment are shown in Fig. 1. Consciousness returned after $8 \mathrm{hr}$ of dialysis; the ethanol infusion was then stopped but haemodialysis was continued for another $7 \mathrm{hr}$. Subsequent follow-up did not reveal visual impairment, changes in the ocular fundi or other neurological deficits. The renal function returned to normal.

\section{Discussion}

The estimated amount of methanol ingested by patients with subsequent fatal outcome is quite variable. However, as the information concerning the amount of ingested methanol is not always precise, the peak serum concentration of methanol may be a 


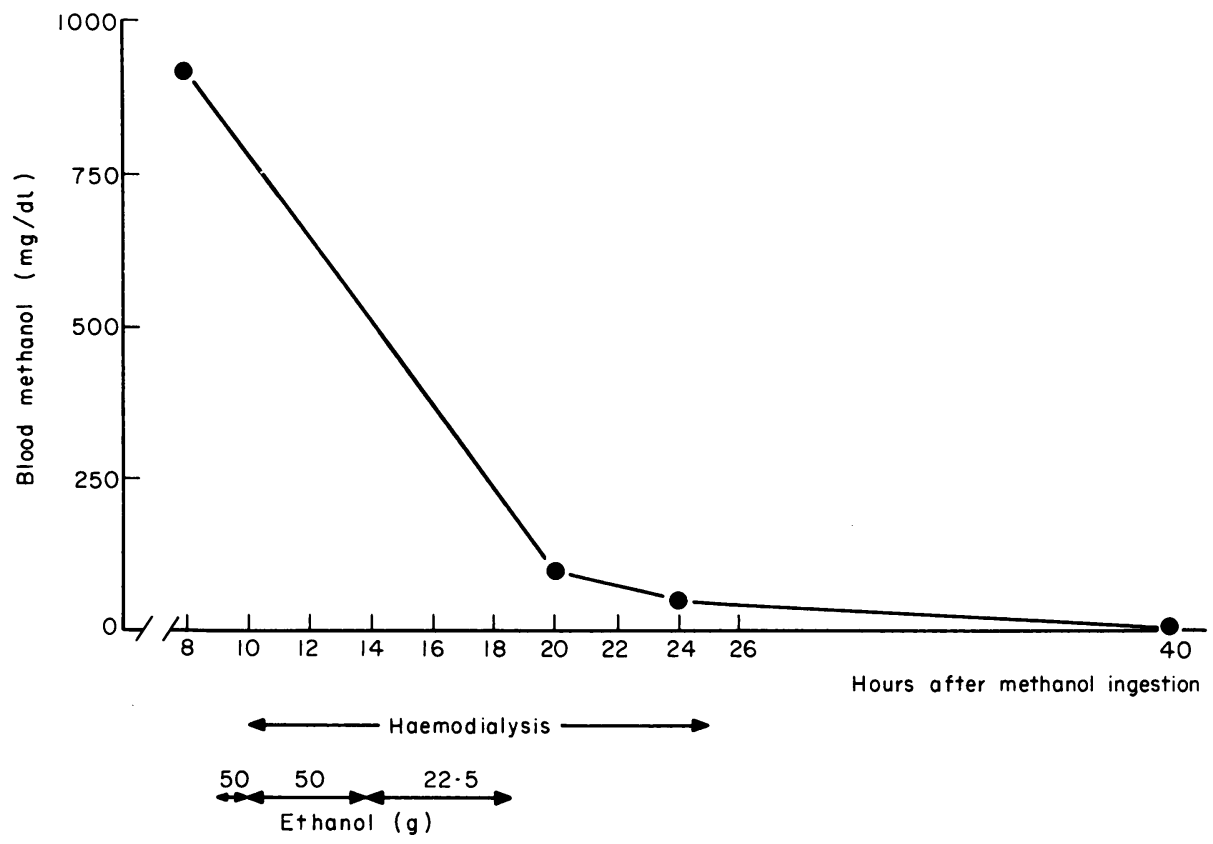

FIG. 1. Recovery without sequelae from severe methanol intoxication.

more reliable index of the severity of poisoning. As far as we know, the peak serum methanol concentration found in our patient exceeds by far the levels reported in other cases not resulting in death or permanent sequelae (Cowen, 1964; Gonda et al., 1978; Keyvan-Larijarni and Tannenberg, 1974; McCoy et al., 1979; Naraqi et al., 1979). The excessively high level in our patient who was also consistent with the osmotic gap of $290 \mathrm{mOsm} / \mathrm{kg}$ $\mathrm{H}_{2} \mathrm{O}$ for which no other reason was found. If we assume that the distribution volume of methanol is 0.6 litres/ $\mathrm{kg}$ of body weight (Koivusalo, 1970), the minimum ingested amount of methanol must have been $420 \mathrm{~g}$.

Many other cases of less severe methanol intoxication have had a less favourable outcome, despite similar treatment (Gonda et al., 1978; Naraqi et al., 1979). We feel that the following considerations may be of importance in relation to the striking individual differences in outcome from methanol poisoning. The time between the moment of ingestion of methanol and the onset of treatment with haemodialysis may be of critical importance. Not methanol itself but its metabolites formaldehyde and most importantly formic acid are responsible for toxicity (McMartin, Ambre and Tephly, 1980). The maximal rate of formation of these metabolites may be delayed for several hours after ingestion, a delay that may be prolonged by recent intake of ethanol. The formation of formic acid is paralleled by the appear- ance of a severe high anion gap metabolic acidosis (McMartin et al., 1980). Our patient had a history of recent ethanol abuse but since ethanol was not detectable in his blood at the moment of admission, this probably could not have substantially delayed the formation of formic acid. On the other hand, blood $\mathrm{pH}$ and serum bicarbonate were not very low on admission but decreased rapidly in the following hours. Haemodialysis and ethanol treatment started at that moment probably prevented dangerous accumulation of formic acid as formic acid is even more effectively dialysable than methanol (McMartin et al., 1980). Effective treatment should not be postponed while awaiting the result of a toxicological examination, as the simultaneous presence of high anion and osmotic gap is indicative of either methanol or ethylene glycol intoxication (Emmet and Narins, 1977), when no low molecular weight substances such as fructose, mannitol or sorbitol have been infused. Both these intoxications require similar treatment with haemodialysis. In our patient haemodialysis treatment was performed for $15 \mathrm{hr}$ and was prolonged for several hours after recovery of consciousness. This is in contrast with other reports with a less favourable outcome in which the duration of haemodialysis was much shorter. Prolonged haemodialysis may have prevented reintoxication from delayed intestinal absorption or redistribution from disequilibrium after dialysis.

Differences in sensitivity to methanol may also 
occur. Recently it was suggested that differences in a folate dependent mechanism for formate oxidation may explain differences in susceptibility among patients (McMartin et al., 1980). Whether folate administration is of help in preventing toxicity from methanol ingestion remains to be shown.

\section{References}

Bennet, I.L., Carey, F.H., Mitchell, G.L. \& CoOper, M.N. (1953) Acute methyl alcohol poisoning: a review based on experience in an outbreak of 323 cases. Medicine (Baltimore), 32, 431.

COWEN, D.L. (1964) Extracorporeal dialysis in methanol poisoning. Annals of Internal Medicine, 61, 134.

EMMET, M. \& NARINS, R. (1977) Clinical use of the anion gap. Medicine, 56, 38.

Gonda, A., Gault, H., Churchill, D. \& Hollomby, D. (1978)
Hemodialysis for methanol intoxication. American Journal of Medicine, 64, 749.

Keyvan-LaRiJaRni, H. \& TANnenberg, A.M. (1974) Methanol intoxication. Comparison of peritoneal dialysis and hemodialysis treatment. Archives of Internal Medicine, 134, 293.

KoIVUSALO, M. (1970) Methanol. In: International Encyclopaedia of $\overrightarrow{\vec{F}}$ Pharmacology and Therapeutics (Ed. by Tremolières, J.), Sec. 20, vol. II, Alcohols and Derivatives, chap. 17. Pergamon Press, New York.

MCCoY, H.G., Cipolle, R.J., Ehlers, S.M., SAwchuk, R.J. \& ZASKE, D.E. (1979) Severe methanol poisoning. Application of a $\vec{\nabla}$ pharmacokinetic model for ethanol therapy and hemodialysis. American Journal of Medicine, 67, 804.

MCMarTin, K.E., AMBRE, J.J. \& TEPHLY, T.R. (1980) Methanol poisoning in human subjects. Role for formic acid accumulation $\vec{O}$ in the metabolic acidosis. American Journal of Medicine, 68, 414.

NARAQI, S., Dethlefs, R.F., SLobodniuk, R.A. \& SaIRERE, J.S. $\vec{\omega}$ (1979) An outbreak of acute methyl alcohol intoxication. Australian and New Zealand Journal of Medicine, 9, 65.

ROECKEL, I.E. \& TALBERT, W.M. (1970) Measurement of methanol in biological fluids. In: Laboratory Diagnosis of Diseases caused by Toxic Agents (Ed. by Sunderman, F.W. \& Sunderman Jr, F.W.), p. 346. Adam-Hilger, London. 